\title{
Asymptomatic bacteriuria in pregnancy in the central region of Iran: Frequency, risk factors, and causative organisms
}

\author{
Aliasghar Farazi $^{\mathrm{a}, *}$, Mansooreh Jabbarias ${ }^{\mathrm{b}}$ \\ a Infectious Diseases Research Center (IDRC), Department of Infectious Diseases, School of Medicine, Arak University of Medical Sciences, Arak, Iran \\ ${ }^{\mathrm{b}}$ Department of Disease Control and Prevention, Health Center of Markazi Province, Arak, Iran
}

\section{A R T I C L E I N F O}

\section{Keywords:}

Asymptomatic bacteriuria

Pregnancy

Risk factors

\begin{abstract}
A B S T R A C T
Introduction: Asymptomatic bacteriuria (ASB) is a common condition that occurring during pregnancy and while untreated can be associated with adverse maternal and perinatal outcomes.

Aim: The aim of this study was to identify the prevalence of ASB in pregnant women referred to prenatal care clinics and determine risk factors and resistance patterns of bacteria isolated from urinary tract infections.

Methods: In a prospective study 220 women without urinary symptoms referred to prenatal care clinics randomly. After obtaining informed consent and complete a demographic questionnaire urine samples were taken and cultured. The isolates from all the cases of ASB were identified and antimicrobial susceptibility was tested by the Kirby- Bauer disc diffusion method.

Results: In this study, the minimum age was 16 years and the maximum was 42 years, mean age was $29.25 \pm 7.56$ years. The average gestational age in women with ASB was $28.7 \pm 6.4$ weeks and in patients without ASB was $27.6 \pm 5.7$ weeks. About $12 \%$ of women had ASB. E. coli was found to be the most common isolate. In this study, educational level, previous history of UTI, non-compliance with preventive measures and multi-parity were risk factors of ASB. The least antibiotics resistance was to nitrofurantoin, ceftriaxone, and norfloxacin.

Conclusion: Routine screening of antenatal women during all trimesters must be considered for preventing the adverse maternal and fetal outcomes particularly with known risk factors like low educational level, multiparity and previous history of UTI.
\end{abstract}

\section{Introduction}

Urinary tract infection is one of the most common infectious diseases that almost $10 \%$ of people in their lifetime will be affected. Urinary tract infections, after upper respiratory tract infections are the most common infection. Urinary tract infection is very important that may be symptomatic or asymptomatic. The prevalence of ASB and symptomatic urinary tract infection in pregnant women increases due to structural and physiologic changes in the urinary tract, which in some cases lead to undesirable conditions for the mother and fetus. ${ }^{1,2}$ Hormonal and structural changes can promote urinary stasis and vesicoureteral reflux and as a result, leads to UTIs among pregnant women. UTIs during pregnancy is associated with risks to pyelonephritis, preterm birth, low birth weight, and increased perinatal mortality.,

ASB is generally defined as the presence of more than 100,000 organisms $/ \mathrm{mL}$ in two consecutive urine samples in the absence of urinary symptoms. ASB happen in $2 \%-10 \%$ of all pregnancies and if untreated can leads to acute cystitis or acute pyelonephritis up to $30 \%-50 \%$ of pregnant mothers. ${ }^{5,6}$ ASB has been associated with preterm birth and low birthweight. Smooth muscle relaxation leads to decreased ureteral and bladder tone and dilatation of the ureters and renal pelvis, urinary stasis and vesicoureteral reflux. Osmolality and $\mathrm{pH}$ changes in urine and pregnancy-induced glycosuria may assist in the bacterial growth and bacterial infection. ${ }^{7,8}$

In addition to these changes, other factors such as age, gender, multiparity, previous history of UTI, socio-economic status and gestational age may increase the prevalence of ASB. Treatment of urinary tract infections is often done empirically on the basis of information obtained from resistance patterns of microorganism. Thereupon due to the increase of microbial resistance, treatment with antibiotics is essential and the therapeutic guidelines must be revised regularly. ${ }^{9,10}$ The aim of this study was to identify the prevalence of asymptomatic bacteriuria in pregnant women referred to prenatal care clinics and determine prevalence and risk factors of ASB and also resistance patterns

\footnotetext{
* Corresponding author. Department of Infectious Diseases, Valiasr Hospital, Arak, Iran.

E-mail addresses: farazialiasghar@yahoo.com, dr.farazi@arakmu.ac.ir (A. Farazi).
} 
of bacterias isolated from urinary tract infections in Arak, Iran.

\section{Methods}

\subsection{Study design}

Over a period of 12 months (from May 2014 to April 2015), the 220 women without urinary symptoms referred to maternal care clinics in Arak city randomly. After obtaining informed consent and complete a structured questionnaire to solicit information on socio-demographic and obstetric characteristics of the mothers and who had symptoms of acute urinary tract infection and those who were on antibiotics or had been on antibiotics at least two weeks prior to the presentation were excluded from the study.

\subsection{Specimen collection and processing}

All mothers after completing the interview were given labeled sterile containers by the interviewer and counseled on how to collect midstream urine and then one urine samples were taken and cultured. If the culture was positive (The quantitative count is $\geq 10^{5} \mathrm{CFU} / \mathrm{mL}$ for voided specimens) second urine sample obtained and culture at intervals of one week later. For women, two positive consecutive specimens are recommended to confirm asymptomatic bacteriuria. However, for women with an initial positive culture which is not subsequently confirmed, transient bacteriuria rather than contamination seems likely. The isolates were identified and antimicrobial susceptibility done by the standardized Kirby-Bauer disc diffusion method on Muller Hinton agar plate. According to recommendations of Clinical Laboratory Standard Institute (CLSI) for antibiotic sensitivity testing and based on the size of inhibition zone around the disc three forms of Sensitive (S), Intermediate (I) and Resistant (R) pattern interpreted. ${ }^{11,12}$

\subsection{Statistical analysis}

According to previous studies ${ }^{3}$ and based on a $95 \%$ confidence interval sample size was calculated as below:

The prevalence of significant bacteriuria in pregnant women $=\% 7.34$

The margin of error $=3.5 \%$

The confidence level $=95 \%$

The population size $=10000$

$\mathrm{n}=\mathrm{n}_{0} /\left[1+\left(\mathrm{n}_{0}-1\right) / \mathrm{N}\right]=220$

Collected data were analyzed using SPSS software (version 18). Statistical Analysis was performed by calculation of mean, standard deviation and significance of proportional differences between nominal variables were determined using the Fisher's exact test or chi-square test, and differences between continuous variables were determined using student t-test. A two-tailed $\mathrm{p}<0.05$ was used to define statistical significance.

\subsection{Ethical issues}

This study was approved by Ethics committee of Arak University of Medical Sciences with the ethics committee reference number of 90118-13 and written informed consent was obtained in all cases.

\section{Results}

\subsection{Patients' characteristics}

In this study, the minimum age was 16 years and the maximum was 42 years, mean age was $29.3 \pm 7.6$ years. The average gestational age in women with asymptomatic bacteriuria $28.7 \pm 6.4$ weeks and in
Table 1

Risk factors in asymptomatic bacteriuria of pregnant mothers.

\begin{tabular}{|c|c|c|c|c|}
\hline Variable & & $\begin{array}{l}\text { Asymptomatic } \\
\text { bacteriuria } 26 \\
(100 \%)\end{array}$ & $\begin{array}{l}\text { Negative } \\
\text { culture } 194 \\
(100 \%)\end{array}$ & P-Value \\
\hline \multirow[t]{3}{*}{ Age (years) } & $<18$ & 4 15.4) & $24(12.4)$ & 0.740 \\
\hline & $18-35$ & $17(65.4)$ & $120(61.9)$ & \\
\hline & $>35$ & $5(19.2)$ & $50(25.8)$ & \\
\hline \multirow[t]{3}{*}{ Gestational age } & $1^{\text {st }}$ trimester & $9(34.6)$ & $78(40.2)$ & 0.8568 \\
\hline & $2^{\text {nd }}$ trimester & $9(34.6)$ & $60(30.9)$ & \\
\hline & $3^{\text {rd }}$ trimester & $8(30.8)$ & $56(28.9)$ & \\
\hline \multirow[t]{3}{*}{ Educational level } & illiterate & $9(34.6)$ & $19(9.8)$ & 0.0012 \\
\hline & $\begin{array}{l}\text { Elementary } \\
\text { and middle } \\
\text { school }\end{array}$ & 7 (26.9) & $65(33.5)$ & \\
\hline & $\begin{array}{l}\text { High school } \\
\text { and university }\end{array}$ & $10(38.5)$ & $110(56.7)$ & \\
\hline \multirow{3}{*}{$\begin{array}{l}\text { Socioeconomic } \\
\text { status }\end{array}$} & Low & $13(50)$ & $74(38.1)$ & 0.5024 \\
\hline & medium & $9(34.6)$ & $86(44.3)$ & \\
\hline & High & $4(15.4)$ & $34(17.6)$ & \\
\hline \multirow{3}{*}{$\begin{array}{l}\text { previous history } \\
\text { of UTI }\end{array}$} & No & $2(7.7)$ & $64(33)$ & 0.0164 \\
\hline & 1 to 3 times & $9(34.6)$ & $63(32.5)$ & \\
\hline & $\begin{array}{l}4 \text { times and } \\
\text { more }\end{array}$ & $15(57.7)$ & $67(34.5)$ & \\
\hline \multirow{3}{*}{$\begin{array}{l}\text { preventive } \\
\text { measures }\end{array}$} & Weak & $16(61.5)$ & $75(34.5)$ & 0.0330 \\
\hline & medium & $8(30.8)$ & $69(35.6)$ & \\
\hline & Good & $2(7.7)$ & $50(25.8)$ & \\
\hline \multirow[t]{2}{*}{ Parity } & nulliparous & $2(7.7)$ & $54(27.8)$ & 0.0268 \\
\hline & Multipara & $24(92.3)$ & $140(72.2)$ & \\
\hline \multirow[t]{3}{*}{ Body mass index } & $<18.5$ & $3(11.5)$ & $23(11.9)$ & 0.4431 \\
\hline & $18.5-24.9$ & $5(19.2)$ & $60(30.9)$ & \\
\hline & $\geq 25$ & $18(69.3)$ & $111(57.2)$ & \\
\hline
\end{tabular}

women without bacteriuria $27.6 \pm 5.7$ weeks.

\subsection{Frequency \& risk factors}

A total of 26 pregnant women (11.6\%) have had asymptomatic bacteriuria. Four mothers (1.8\%) were considered as transient bacteriuria in young women under the age of 25 years and was in the first half of pregnancy. Also, none of the mothers have two consecutive cultures with different microorganisms. In urinalysis presence of nitrite, leukocytes and bacteria in the urine have sensitivity \%73, \%69 and \%50 and specificity of $\% 86, \% 83$ and $\% 82$ respectively for diagnosis of ASB. In this study, educational level, previous history of UTI, non-compliance with preventive measures and multi-parity were risk factors of asymptomatic bacteriuria in pregnant women as well as body mass index, socioeconomic status, Maternal age and gestational age were not associated with bacteriuria (Table 1).

\subsection{Causative organisms \& antibiotic susceptibility tests}

The most common isolate was E. coli $(46.2 \%)$, followed by the Staphylococcus saprophyticus (23.1\%), Klebsiella (15.4\%), Enterobacter (7.7\%) and Streptococcus Group B (7.7\%). The maximum antibiotics resistance was to three drugs cotrimoxazole, nalidixic acid and Amoxicillin/clavulanate and the least resistance was to nitrofurantoin, ceftriaxone, and norfloxacin (Table 2, Fig. 1).

\section{Discussion}

ASB in pregnancy is a cause of serious maternal and perinatal morbidity. This morbidity can be reduced with the screening of pregnant mothers and giving appropriate treatment. In this study, the prevalence of ASB was $11.8 \%$. In other studies, the prevalence of ASB was reported from $7.2 \%$ to $45.3 \% .^{5,13,14}$ This discrepancy may be arising from differences in the community health infrastructure, socio-economic status, social habits, and education of the patients who were studied. ${ }^{15}$ 
Table 2

Antimicrobial resistance pattern of isolated organisms.

\begin{tabular}{|c|c|c|c|c|c|}
\hline Antibiotics & Escherichia coli (\%) & Enterococcus spp. (\%) & Streptococcus group B (\%) & Staphylococcus saprophyticus (\%) & Klebsiella spp. (\%) \\
\hline Ciprofloxacin & 14.3 & 33.3 & 0 & 14.3 & 0 \\
\hline Amoxicillin/clavulanate & 50 & 100 & 0 & 28.6 & 50 \\
\hline Ceftizoxime & 7.1 & 0 & 0 & 42.9 & 25 \\
\hline Gentamicin & 28.6 & 0 & 50 & 57.1 & 25 \\
\hline Cephalexin & 28.6 & 33.3 & 0 & 57.1 & 75 \\
\hline Ceftriaxone & 7.1 & 33.3 & 0 & 57.1 & 0 \\
\hline Ampicillin & 21.4 & 33.3 & 0 & 57.1 & 50 \\
\hline Cefixime & 14.3 & 33.3 & 0 & 57.1 & 75 \\
\hline Norfloxacin & 7.1 & 0 & 0 & 14.3 & 0 \\
\hline Cotrimoxazole & 64.3 & 66.7 & 0 & 42.8 & 50 \\
\hline Nitrofurantoin & 0 & 33.3 & 0 & 14.3 & 0 \\
\hline Nalidixic Acid & 50 & 33.3 & 50 & 71.4 & 25 \\
\hline
\end{tabular}

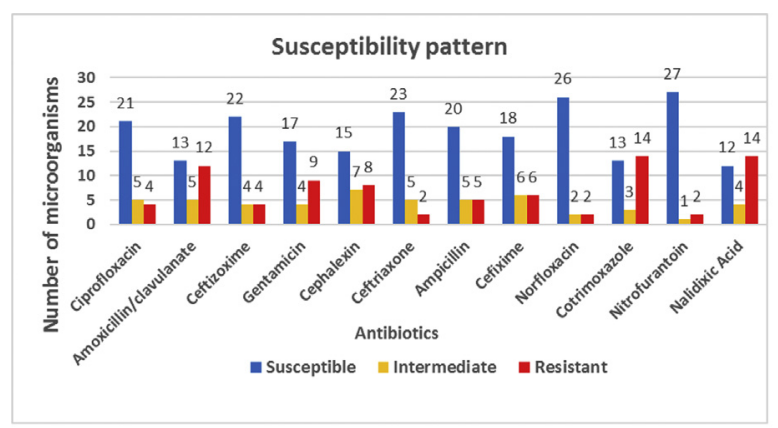

Fig. 1. Antibiotic susceptibility pattern of isolated bacteria from pregnant women.

The highest prevalence of asymptomatic bacteriuria was found in the age group of $18-35 y$ rs $(65.4 \%)$. Similar results are also found in some studies which have found a significant association with age and showing that ASB is common with advancing age but other studies also reported a higher prevalence in the age group of 20-25 years. ${ }^{10,14,16}$

Our study showed the prevalence of ASB was highest among multipara (92.3\%). Other studies reported a similar association and like our study more cases of ASB occurred in multigravida (51.1\%) than in primigravida. ${ }^{14,17,18}$

In this study, a higher rate of infection was detected in 1st and 2nd trimester of pregnancy $(34.6 \%)$, followed by third trimester $(30.8 \%)$ which is similar to the other studies that reported the incidence of ASB was highest in the 1st trimester and during the 2nd trimester. Findings from our and other studies are inferred that screening for ASB should be done in all the three trimesters of pregnancy to prevent the serious complications associated with ASB in pregnancy. ${ }^{17-21}$

Among the risk factors associated with ASB, the highest prevalence was seen in patients with a previous history of UTI (53.8\%). Other studies showed a similar association. $3,10,15$

In this study, Escherichia coli (46.2\%) was found to be the commonest isolate, followed by the Staphylococcus species (23.1\%), Klebsiella (15.4\%), Enterobacter (7.7\%) and Streptococcus Group B (7.7\%). Similar results are reported by others who have reported Escherichia coli as the commonest isolate, but some studies also reported Klebsiella species as the commonest micro-organism. ${ }^{17}, 22-24$ Although the antibiotic susceptibility patterns of microorganisms in ASB are disparate in the different geographical area due to an indiscriminate usage of antibiotics and therefore the emergence of resistant strains. For this reason, an effective antibiotic treatment based on susceptibility patterns is recommended.

\section{Conclusion}

The prevalence of ASB seen in pregnant women in our study was $11.8 \%$ and E. coli was the dominant organism isolated. Quantitative urine culture is the ideal test for detection of ASB. Early detection and treatment are essential to protect the health of mother and fetus. Because of the low sensitivity of urine analysis (dipstick urinalysis), it is recommended for all pregnant women during the first trimester of pregnancy, a urine culture was taken and if there is no ASB the urine culture be repeated in the second and third trimester.

\section{Author contributions}

AF was involved in the conception and design, data acquisition, analysis and interpretation, and drafting and revising the manuscript. MJ was involved in the conception and design, data acquisition, drafting and revising the manuscript. All authors read and approved the final manuscript.

\section{Funding}

This research did not receive any specific grant from funding agencies.

\section{Conflicts of interest}

The authors declare that they have no competing interests.

\section{Acknowledgements}

The author thankfully acknowledges Deputy of Research of Arak University of Medical Sciences and Infectious Diseases Research Center.

\section{Appendix A. Supplementary data}

Supplementary data to this article can be found online at https:// doi.org/10.1016/j.cegh.2018.09.009.

\section{References}

1. Nicolle LE. Urinary tract infection. Crit Care Clin. 2013;29(3):699-715.

2. Farazi A, Rasi H, Arjomandzadegan M, Kamarbandi Sharah A, Salimi M. Frequency and susceptibility pattern of urinary bacterial pathogens in patients referred to Imam Reza specialized polyclinic in Arak, 2012-2013, Iran. Qom Univ Med Sci J. 2015;9(6):37-45 ([Persian]).

3. Chandel LR, Kanga A, Thakkur K, Mokta KK, Sood A, Chauhan S. Prevalence of pregnancy associated asymptomatic bacteriuria: a study done in a tertiary care hospital. J Obstet Gynaecol India. 2012;62(5):511-514.

4. McCormick T, Ashe RG, Kearney PM. Urinary tract infection in pregnancy. Obstet Gynaecol. 2008;10:156-162.

5. Imade PE, Izekor PE. Asymptomatic bacteriuria among pregnant women. N Am J Med Sci. 2010;2(6):263-266.

6. Cai T, Mazzoli S, Mondaini N, et al. The role of asymptomatic bacteriuria in young women with recurrent urinary tract infections: to treat or not to treat? Clin Infect Dis. 2012;55:771-777.

7. Schnarr J, Smaill F. Asymptomatic bacteriuria and symptomatic urinary tract infections in pregnancy. Eur J Clin Invest. 2008;38(S2):50-57.

8. Jayalakshmi J, Jayaram VS. Evaluation of various screening tests to detect 
asymptomatic bacteriuria in pregnant women. Indian $J$ Pathol Microbiol. 2008;51(3):379-381.

9. Gayathree L, Shetty S, Deshpande SR, Venkatesh DT. Screening for asymptomatic bacteriuria in pregnancy: an evaluation of various screening tests in Hassan District Hospital, India. J Clin Diagn Res. 2010;4(4):2702-2706.

10. Rohini UV, Reddy GS, Kandati J, Ponugoti M. Prevalence and associated risk factors of asymptomatic bacteriuria in pregnancy with bacterial pathogens and their antimicrobial susceptibility in a tertiary care hospital. Int J Reprod Contracept Obstet Gynecol. 2017;6:558-562.

11. Performance Standards for Antimicrobial Disc Susceptibility Tests; Approved Standard. twelfth ed. Wayne, PA.USA: M02-A12. National Committee for Clinical Laboratory Standards; 2015 32(1)

12. National Committee for Clinical Laboratory Standards. Performance Standards for Antimicrobial Susceptibility Testing: Twelfth Information Supplement. NCCLS Document M100-S12 Wayne, PA: NCCLS; 2002.

13. Neupane HC, Adhikari S, Aryal B. Asymptomatic bacteriuria among pregnant women attending the outpatient clinics of chitwan medical college teaching hospital in chitwan, Nepal. IRJP. 2012;3(11):78-80.

14. Sujatha R, Nawan M. Prevalence of asymptomatic bacteriuria and its antibacterial susceptibility pattern among pregnant women attending the antenatal clinic at kanpur, India. J Clin Diagn Res. 2014;8(4):DC01-3.

15. Rajaratnam A. Diagnosis of asymptomatic bacteriuria and associated risk factors among pregnant women in mangalore, Karnataka, India. J Clin Diagn Res.
2014;8(9):OC23-O26.

16. Alghalibi SM, Al-Jaufy A, Al-Moayad E. Bacterial urinary tract infection among pregnant women in Sana'a City-Yemen. Arab Gulf J Sci Res. 2007;25:23-31.

17. Ramalingam K, Surasani VM, Bollu M. Prevalence of asymptomatic bacteriuria in antenatal women coming to NRIMC and GH, Bangladesh. J Obstet Gynaecol 2015;30(1):30-36.

18. Roy SK, Sinha GR, Qudros MA. A study of bacteriuria in pregnancy. J Obstet Gynaecol India. 1974;24:244-251.

19. Saeed S, Tariq P. Symptomatic and asymptomatic urinary tract infections during pregnancy. Int J Microbiol Res. 2011;2(2):101-104.

20. Yashodhara P, Mathur R, Raman L. Urinary tract infection in pregnancy. Indian J Med Res. 1987;86:309-314.

21. Nath G, Chaudhary M, Prakash J, Pandey LK, Singh TB. Urinary tract infection during pregnancy and foetal outcome. Indian J Med Microbiol. 1996;14:158-160.

22. Muharram SH. A preliminary assessment of asymptomatic bacteriuria of pregnancy in Brunei Darussalam. Malaya J Med Sci. 2014;21(2):34-39.

23. Olamijulo Joseph Ayodeji. Chris olu adewale and olalekan olaleye asymptomatic bacteriuria among antenatal women in Lagos. J Obstet Gynaecol (Basingstoke). 2016;36:6

24. Garnizov TM. Asymptomatic bacteriuria in pregnancy from the perspective of public health and maternal health care: review and case report. Biotechnol Biotechnol Equip. 2016;30(3):443-447. 